\title{
Usefulness of Sacubitril/Valsartan in reduction of atrial fibrillation burden in a patient with ICD delivering inappropriate therapies. A new possibility?
}

\author{
Matteo Casalea, Maurizio Mezzettia, Marianna Gigliotti De Faziob, \\ Marco Morellia, Loredana Caccamoa , Paolo Busaccaa , Giuseppe Dattilob
}

a Hospital S. Maria della Misericordia, Operative Unit of ICCU and Cardiology, ASUR Marche - Area Vasta 1, Urbino, Italy

${ }^{b}$ Department of Clinical and Experimental Medicine, University of Messina, Italy

\section{ARTICLE INFO}

\section{Article history:}

Submitted: 27. 12. 2019

Revised: 10. 1. 2020

Accepted: 11. 1. 2020

Available online: 13. 7. 2020

\section{Klíčová slova:}

Fibrilace síní

ICD

Implantabilní přistroj pro úpravu

srdečního rytmu

Sacubitril/valsartan

Srdeční selhání

Keywords:

Atrial fibrillation

Cardiac implantable devices

Heart failure

ICD

Sacubitril/Valsartan
SOUHRN

Srdeční selhání je v současnosti onemocněním s obrovskými důsledky pro klinickou praxi i náklady na zdravotní péči. Léčba př́stroji, jako jsou implantabilní kardioverter-defibrilátor (implantable cardioverter-defibrillator, ICD), se neustále vyvíjí a často dokáže zachránit život, v některých případech však pouze málo ovlivní symptomy. Optimální léčba často nedokáže zastavit progresi onemocnění; výsledkem je vznik arytmií (např. fibrilace síní), které by mohly být příčinou nežádoucích výbojů z ICD. Popisujeme případ pacienta S ICD, u něhož bylo provedeno kardiologické vyšetření na oddělení akutních př́imů pro opakované epizody dyspnoe a palpitací. $V$ tomto případě byl zvolen konzervativní přístup s podáním kombinace sacubitril/valsartan spíše než použití jiných, invazivnějších metod, které by jinak bylo nutno v klinické praxi pro odstranění problému zkusit.

(c) 2020, ČKS.

\section{ABSTRACT}

Heart failure (HF) is currently a condition with high impact both in terms of clinical practice and of health care costs. Therapy with cardiac devices such as implantable cardioverter-defibrillators (ICD) is constantly evolving and often it is life-saving. However, in some cases it has minimal clinical impact on the symptoms. An optimal therapy is often not sufficient to avoid progression of the pathology, leading to arrhythmias such as atrial fibrillation, which could cause inappropriate delivery of therapies from the ICD. We describe the case of a patient with ICD who underwent cardiac evaluation in the Emergency Department because he experienced multiple episodes of dyspnea and palpitations. In this case a conservative approach by administration of Sacubitril/Valsartan avoided other more invasive approaches that otherwise in clinical practice should be attempted to avoid inappropriate shocks. 


\section{Introduction}

Heart failure (HF) is to date a very important clinical diagnosis because of its implications in terms of clinical practice and of health care costs. ${ }^{1}$ HF causes a remodeling of cardiac chambers leading to arrhythmias such as atrial fibrillation, ${ }^{2}$ which complicate the clinical scenario. Patients with optimal medical therapy and severely impaired ejection fraction need the implantation of an ICD in order to improve survival ${ }^{3}$ and, in presence of left bundle branch block and wide QRS, often the best solution is a CRT implantation. ${ }^{4}$ Many patients with an ICD implanted have an improved survival but the concomitant presence of atrial fibrillation can lead to inappropriate therapy delivery from the device, with early battery consumption and high level of discomfort for the patient. Recently the introduction of Sacubitrl/Valsartan therapy showed an improvement of the prognosis of patients not responding to optimal medical therapy. ${ }^{1}$ Furthermore this therapy reduced the incidence of ventricular arrhythmias besides left ventricular reverse remodeling. ${ }^{5}$ However, its implications on atrial fibrillation burden is currently not well understood.

\section{Case report}

We report the case of a 54-year-old male patient who went to the Emergency Department complaining about dyspnoea and reduced effort tolerance for several months. In his medical history was reported three years before an implantation of ICD in primary prevention because of a dilated cardiomyopathy with normal coronary arteries. Two years before he reported five accesses in the Emergency Department because of persistent atrial fibrillation treated with electrical cardioversions. The patient always refused electrical insulation of pulmonary veins by radiofrequency ablation and received Flecainide $200 \mathrm{mg}$ with slow release formulation, substituted 12 months before the last access with Amiodarone $200 \mathrm{mg}$ o.d. because of clear contraindication, in absence of left ventricular reverse remodeling. He was in therapy with Apixaban $5 \mathrm{mg}$ $1 \mathrm{cp}$ bid because of a CHADS-VASC score of 2 (he suffered from hypertension and had a clear diagnosis of HF). ${ }^{6}$
Despite HF medical therapy with Ramipril 10 mg, Canrenone $50 \mathrm{mg}$ and Bisoprolol $5 \mathrm{mg}$ (with impossibility to titrate further the therapy because of bradycardia) ejection fraction was $35 \%$. The ECG showed atrial fibrillation with an average ventricular response of 130 beats per minute. Device interrogation showed a high burden of atrial fibrillation during therapy with Amiodarone, sometimes with high ventricular frequency, for nine months (Fig. 1). In two cases the device delivered therapy with anti-tachycardia pacing (ATP) without inappropriate shocks. The patient did not tolerate higher dosages of beta-blocker because of important bradycardia during sinus rhythm. In this setting he continued to refuse electrical insulation of pulmonary veins. Because of the presence to chest X-Ray of signs of HF the patient was admitted in the Cardiology Department. After brief (about 6 hours) diuretic i.v. therapy with furosemide there was an improvement in symptoms. Because of a normal renal function (serum creatinine was $0.8 \mathrm{mg} / \mathrm{dl}$ ) and adequate blood pressure (120/75 $\mathrm{mmHg}$ ) Ramipril and Canrenone were suspended and a therapy with Sacubitril/Valsartan 49/51 mg bid was started. Because of inadequacy of Amiodarone in this context it was explained the risk of bradycardia with subsequent need for device upgrade to a DDD pacing. The patient declared its willingness to not proceed to a potential future upgrade so further increase was not attempted. He was discharged after three days in atrial fibrillation with an average ventricular frequency of $90 \mathrm{bpm}$. At one-month follow-up the patient reported a subjective improvement of his health status but the echocardiogram did not show significant differences in terms of ejection fraction (35\%) neither in terms of heart chambers dimensions (left ventricle and left atrium in sinus rhythm were mildly dilated with a diameter of $56 \mathrm{~mm}$ for the ventricle and an area of $21 \mathrm{~cm}^{2}$ for the atrium). In particular the patient was in sinus rhythm (with an ECG showing heart rate of $52 \mathrm{bpm}$ ) for three days. The therapy with amiodarone was not adequate because of its additional beta-blocking effect (the patient was prone to bradycardia) and of its side effects in the long term: the patient was developing corneal disturbances as stated in a recent evaluation from the ophthalmologist. ${ }^{7}$ The Sacubitril/Valsartan was well tolerated an so the cardiologist increased the dose to $97 / 103 \mathrm{mg}$ bid and suspended Amiodarone.

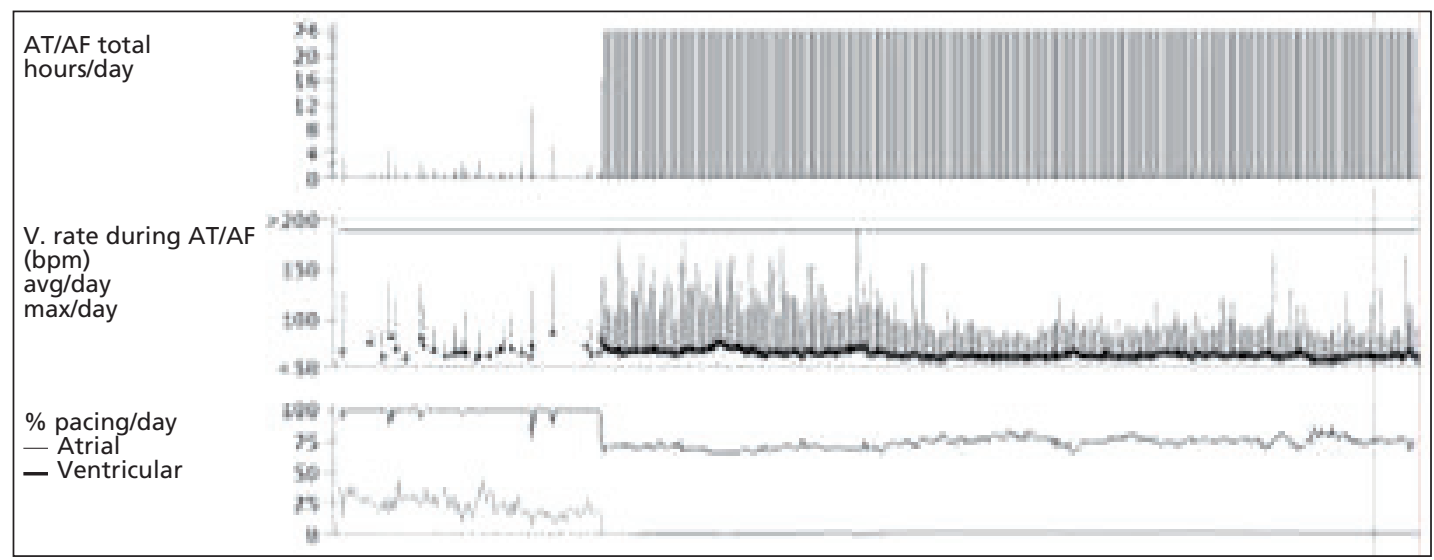

Fig. 1 - Device report documenting high burden of atrial fibrillation before starting Sacubitril/Valsartan therapy from more than one month. 


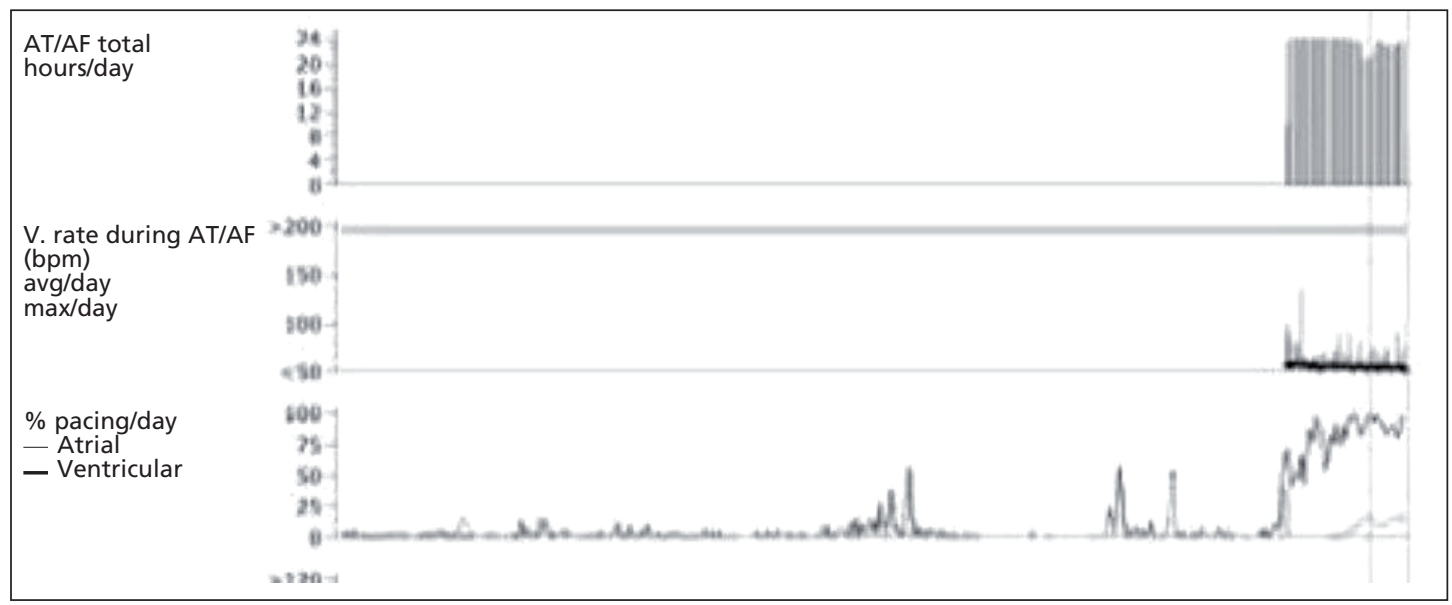

Fig. 2 - Device report at one year shows that after six months of therapy with Sacubitril/Valsartan there is a net reduction of atrial fibrillation burden.

At six months the device statistics showed persistence of sinus rhythm despite any change in the echocardiogram. Improvement of EF was observed only after one year and was quantified in $45 \%$ with a concomitant normalization of heart chambers dimensions (left ventricle diameter was $53 \mathrm{~mm}$ and left atrium area reduced to $20 \mathrm{~cm}^{2}$ ). Device interrogation during the 12-month follow-up showed that after the hospital admission and the introduction of therapy with Sacubitril/Valsartan the burden of atrial fibrillation was reduced and that the patient experienced a new episode of persistent atrial fibrillation only one month before, without any symptom (Fig. 1).

\section{Discussion}

Sacubitril/Valsartan therapy demonstrated several beneficial effects in the PARADIGM trial. ${ }^{1}$ Despite an effect on reverse remodeling and improvement of ejection fraction, currently there are not studies proving beneficial effects on atrial fibrillation burden. In patients with implanted cardiac devices several conditions leading to HF could complicate the clinical scenario..$^{8,9}$

This case is of particular interest because a patient with HF and paroxysmal atrial fibrillation could be prone to inappropriate therapy delivery by the device even by proper device programming. ${ }^{10}$ In our case in fact the device was programmed, according to current literature, ${ }^{10}$ with a single ventricular fibrillation zone ( $\geq 220 \mathrm{bpm})$ and a single monitor zone (171-219 bpm). With this setting therapies delivered were only ATPs during capacitors charge in two cases of high ventricular rate atrial fibrillation. However, inappropriate shocks could be the main complication in this kind of patients, leading to high level of discomfort for the patient, to hospitalization and battery consumption. ${ }^{1}$ Drug therapy in this case did not show a clear efficacy despite beta-blockers were already at the maximum tolerated dose. Furthermore Amiodarone was not effective in controlling the arrhythmia and was showing clear side effects (corneal disturbances). There were only limited possibilities of treatment in this subject and mainly by an electrical insulation of pulmonary veins by radiofrequency, which was refused.

The main surprising aspect of these patients is that therapy with Sacubitril/Nalsartan reduced rapidly the burden of atrial fibrillation even without overt cardiac remodeling. Even if a tachycardiomyopathy could be considered as a precipitating factor, in this case ejection fraction and cardiac chambers dimensions were the same for three years. The interesting element is that despite echocardiogram showed similar data at six-month follow-up, there was a significant reduction of atrial fibrillation burden. Even if echocardiography showed great importance for a proper diagnosis even in difficult scenarios, ${ }^{11}$ in this case there was absence of overt echocardiographic improvement. It is possible that the drug had an incidence on atrial electrical remodeling with some kind of antiarrhythmic effect, even before the reduction of left atrium dimension. Many conditions different from coronary artery disease leading to HF may have benefit from advanced non-pharmacological therapy..$^{12,13}$ While the exact impact in different cardiac disorders ${ }^{14,15}$ is currently under investigation and new interesting therapeutic perspectives are currently emerging, ${ }^{16}$ it is clear that HF is more complex than believed. The use of cardiac devices poses problems deriving both from patients ${ }^{17}$ and from the risk of infections ${ }^{18}$ even if it is often necessary.

\section{Conclusions}

Many of neuro-hormonal modifications induced by Sacubitril/Valsartan show that the beneficial effect is before an overt improvement in terms of cardiac reverse remodeling. It is probably too early to state that this drug therapy could express an antiarrhythmic effect in terms of atrial fibrillation burden but it is clear that currently the concept of "optimal medical therapy" is evolving.

\section{Conflict of interest}

None. 


\section{References}

1. Ponikowski P, Voors AA, Anker SD, et al. 2016 ESC Guidelines for the diagnosis and treatment of acute and chronic heart failure. Eur Heart J 2016;37:2129-2200.

2. Kirchhof P, Benussi S, Kotecha D, et al. 2016 ESC Guidelines for the management of atrial fibrillation developed in collaboration with EACTS. Europace 2016;18:1609-1678.

3. Moss AJ, Hall WJ, Cannom DS, et al. Improved survival with an implanted defibrillator in patients with coronary disease at high risk for ventricular arrhythmia. Multicenter Automatic Defibrillator Implantation Trial Investigators. N Engl J Med 1996:335:1933-1940.

4. Bristow MR, Saxon LA, Boehmer J, et al. Cardiac-resynchronization therapy with or without an implantable defibrillator in advanced chronic heart failure. N Engl J Med 2004;350:2140-2150.

5. Martens P, Nuyens D, Rivero-Ayerza M, et al. Sacubitril/ valsartan reduces ventricular arrhythmias in parallel with left ventricular reverse remodeling in heart failure with reduced ejection fraction. Clin Res Cardiol 2019;108:1074-1082.

6. Dattilo G, Falanga G, Casale M, et al. Oral Anticoagulants: Old and New Therapy. In: Berhardt LV, ed. Advances in Medicine and Biology. New York: Nova Science Publishers, Inc., 2015:1370.

7. Casale M, Mezzetti M, Tulino V, et al. Therapy of Cardiac Arrhythmias in Children: An Emerging Role of Electroanatomical Mapping Systems. Curr Vasc Pharmacol 2018;16:528-533.

8. Casale M, Quattrocchi S, Bitto R, Dattilo G. Cardiac implantable devices and Takotsubo syndrome. A rare but potential eventuality. Cor Vasa 2018;60:e500-e502.

9. Scarano M, Gizzi G, Mastrodicasa D, Mantini C. Cardiac implantable electronic devices and chemotherapy: A risky combination. Cor Vasa 2018;60:e469-e471.

10. Clementy N, Challal F, Marijon E, et al. Very high rate programming in primary prevention patients with reduced ejection fraction implanted with a defibrillator: Results from a large multicenter controlled study. Heart Rhythm 2017;14:211-217.

11. Imbalzano E, Di Bella G, Casale M, et al. Angina pectoris: first manifestation of a left atrial myxoma. Int J Cardiol 2014;172(1):e165-166.

12. Scarano M, Gizzi G, Mantini C. Arrhythmogenic cardiomyopathy of left ventricle. A rare event, but possible. Cor Vasa 2018;60:e508-e511.

13. Parato VM, Clemente D, Muscente F, et al. Combined orthotopic heart transplantation followed by autologous stem cell transplantation in a patient with light chain amyloidosis and isolated cardiac involvement. Cor Vasa 2018;60:e518-e521.

14. Dattilo G, Borgia F, Guarneri C, et al. Cardiovascular Risk in Psoriasis: Current State of the Art. Curr Vasc Pharmacol 2019;17:85-91.

15. Di Bella G, Minutoli F, Piaggi P, et al. Quantitative Comparison Between Amyloid Deposition Detected by $(99 \mathrm{~m})$ Tc-Diphosphonate Imaging and Myocardial Deformation Evaluated by Strain Echocardiography in Transthyretin-Related Cardiac Amyloidosis. Circ J 2016;80:1998-2003.

16. Dattilo G, Casale M, Avventuroso E, Laganà P. Vitamin D Dietary Supplementation: Relationship with Chronic Heart Failure. J AOAC Int 2018;101:939-941.

17. Casale M, Imbalzano E, Dattilo G. Twiddler syndrome: A rare complication with important clinical relevance. J Cardiol Ther 2014;1:108-110.

18. Laganà $P$, Delia $S$, Avventuroso $E$, et al. Risk Assessment of Legionellosis in Cardiology Units. J Prev Med Hyg 2017;58:E173-E176. 